\title{
Pengaruh Tension Crack (Tegangan Retak) pada Analisis Stabilitas Lereng menggunakan Metode Elemen Hingga
}

\author{
FRIZKIA AZIFA SILMI, INDRA NOER HAMDHAN
}

\author{
Jurusan Teknik Sipil, Institut Teknologi Nasional, Bandung \\ Email: frizkiaas@gmail.com
}

\begin{abstract}
ABSTRAK
Kondisi kemarau yang terus menerus menyebabkan kondisi lingkungan sekitar menjadi kekeringan. Jika hal tersebut terjadi pada tanah khususnya lereng maka akan menimbulkan tegangan retak dan memicu terjadinya kelongsoran. Pemodelan ini mengkolaborasikan antara kedalaman tegangan retak, posisi tegangan retak serta kemiringan lereng dengan kondisi tanah tidak jenuh air dan kondisi tanah jenuh air menggunakan PLAXIS 2D dengan metode elemen hingga. Dari hasil analisis diperoleh nilai faktor keamanan untuk kondisi tanah tidak jenuh air berada pada 1,6-1,8 dengan kondisi aman sedangkan untuk kondisi jenuh air untuk kemiringan 1:1 dibawah satu atau berada pada kondisi tidak aman, kemiringan 1:1,5 dan kemiringan 1:2 berada pada 1,4-1,5 dengan kondisi aman.
\end{abstract}

Kata kunci: tegangan retak, lereng dan Metode Elemen Hingga

\begin{abstract}
Drought conditions that continue to cause environmental conditions become dry. If it happens to the ground especially the slope it will cause a Tension crack and trigger the occurrence of sliding. This model is collaborated among a depth of tension crack, position of tension crack and slope gradient with unsaturated soil condition and saturated soil condition using PLAXIS 2D with finite element method. The analysis result for the condition of unsaturated soil is at 1.6-1.8 with safe condition and for saturated soil condition for slope of 1: 1 under one or is in unsafe condition, slope of 1:1,5 and slope of 1:2 are at 1.4-1.5 with safe conditions.
\end{abstract}

Keyword: tension crack, slope dan Finite Elemen Method 


\section{PENDAhUlUAN}

\subsection{Latar Belakang}

Indonesia adalah negara tropis, yang artinya hanya ada dua musim di negara tersebut. Musim tersebut adalah musim hujan dan musim kemarau. Musim kemarau itu adalah suatu musim dimana curah hujan per bulannya sangat rendah. Kondisi musim tersebut menyebabkan tanah dalam kondisi tidak jenuh atau tanah menjadi kering karena sedikitnya curah hujan yang diserap oleh tanah serta kondisi suhu udara pada musim tersebut cukup terik sehingga air yang menyerap ke dalam tanah mengalami penguapan. Jika musim kemarau terjadi berkepanjangan, seiring berjalannya waktu, kondisi tanah tersebut mengalami kekeringan yang nantinya tanah tersebut terancam mengalami tension crack (tegangan retak).

\subsection{Tujuan Penelitian}

Tujuan penelitian ini dimaksudkan untuk menganalisis stabilitas lereng pada kondisi tanah yang mengalami tegangan retak (tension crack) dengan berbagai macam kondisi dengan metode elemen hingga agar mengetahui kestabilan tanah tersebut.

\section{TINJAUAN PUSTAKA}

\subsection{Jenis-jenis Gerakan Tanah dan Longsoran}

Istilah "longsor" menggambarkan berbagai proses dalam menghasilkan gerakan ke bawah dan keluar dari material pembentuk lereng termasuk batu, tanah, pengisi buatan ataupun kombinasi dari ketiganya. Material memungkinkan untuk berpindah dengan cara runtuhan (falling), longsoran (slides), sebaran (spreads), atau aliran (flowing), pengelupasan (topples) dan sebaran lateral (lateral speads). Pada Gambar 1 menunjukkan ilustrasi dari kelongsoran dengan terminologi yang diterima secara umum yang menjelaskan fitur-fiturnya.

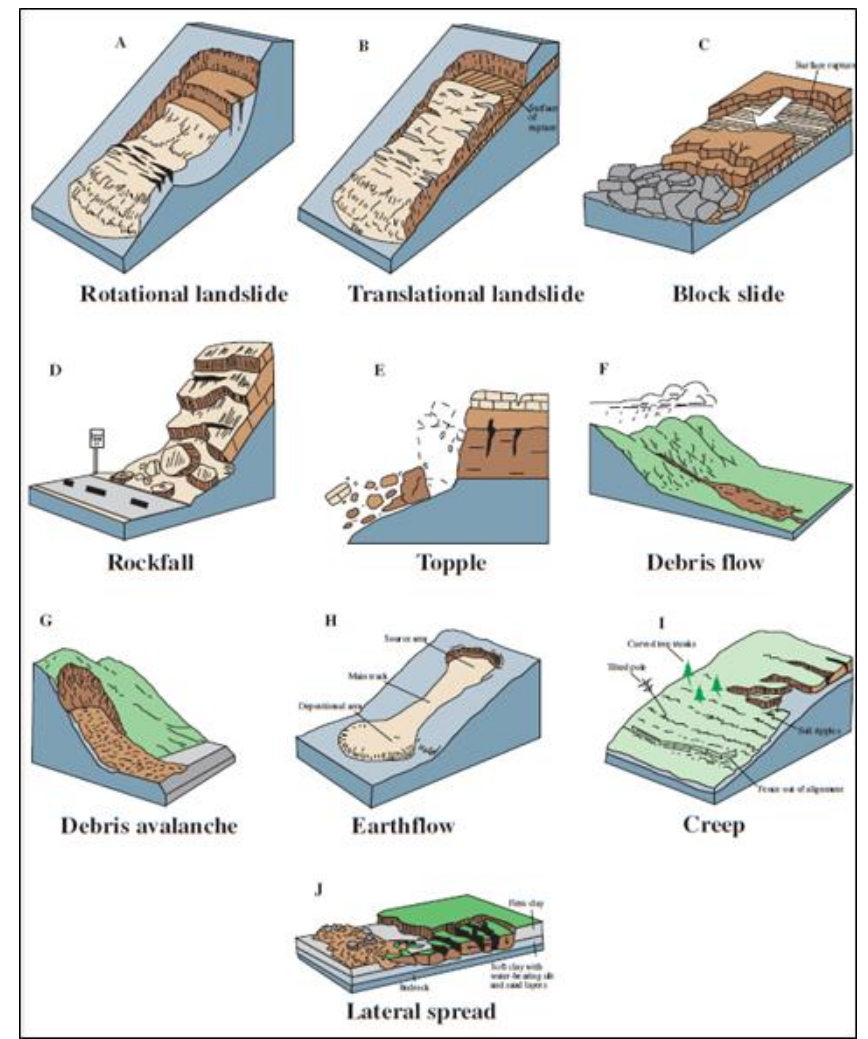

Gambar 1. Jenis-jenis utama gerakan tanah longsor (Sumber: USGS, 2004) 


\subsection{Stabilitas Lereng}

Lereng adalah massa tanah yang terletak dibawah permukaan tanah yang miring atau dibawah sisi miring, memiliki kecenderungan bergerak ke arah luar karena pengaruh gravitasi. Seandainya kecenderungan ini ditiadakan oleh tahanan geseran tanah, maka lereng berada dalam keadaan stabil. Pada kondisi sebaliknya penggelinciranlah yang terjadi. Oleh karena itu, teori kestabilan lereng dibutuhkan. Lereng dapat dikatakan stabil apabila nilai dari faktor keamanannya melebihi satu. Menurut Das (2010) faktor keamanan Persamaan 1 didefinisikan sebagai:

$$
S F=\frac{\tau_{f}}{\tau_{d}}
$$

halmana:

$S F \quad=$ angka keamanan terhadap kekuatan tanah,

$\tau_{f} \quad=$ kekuatan geser rata-rata dari tanah $\left[\mathrm{kN} / \mathrm{m}^{2}\right]$,

$\tau_{d} \quad=$ tegangan geser rata-rata yang bekerja sepanjang bidang longsor $\left[\mathrm{kN} / \mathrm{m}^{2}\right]$.

\subsection{Efek Tegangan Retak (Tension Crack) pada Analisis Stabilitas}

Retakan sering ditemukan di puncak lereng tanah dan batuan. Keberadaan retakan tersebut menunjukkan bahwa dalam zona tertentu, tegangan tarik melebihi kekuatan tarik (Baker, 1981). Efek dari tegangan retakan terhadap stabilitas lereng dibagi menjadi beberapa hal, diantaranya:

a. Kekuatan geser akibat lekatan dan gesekan tanah berkurang akibat adanya retakan.

b. Tekanan air yang bekerja pada permukaan retakan merupakan suatu kekuatan yang mendorong untuk terjadinya kelongsoran.

c. Air yang berada didalam celah retakan cenderung melunakkan tanah sehingga kekuatan tanah tersebut berkurang.

Oleh karena itu, sangat diharapkan untuk mampu meramalkan kedalaman dimana retakan itu akan muncul dan memperhitungkan efek stabilitasnya. Terutama, sangat penting untuk menentukan kondisi-kondisi dimana tidak ada retakan yang akan diharapkan untuk muncul, sekaligus menghindari efek pelunakan yang mana sulit untuk dianalisa secara kuantitatif. Lebih jauh lagi, saat kedalaman retakan diketahui, tidaklah sulit untuk membuat nilai yang tepat pada efek dari analisis stabilitas yang merupakan penentuan dari kedalaman retakan yang tetap menjadi rantai yang lemah dalam perhitungan stabilitas lereng Gambar 2. Kedalaman retakan Persamaan $\mathbf{2}$ ini secara teori dapat didefinisikan:

$$
z_{c}=\frac{2 c}{\gamma} \tan ^{2}\left(45+\frac{1}{2} \phi\right)
$$

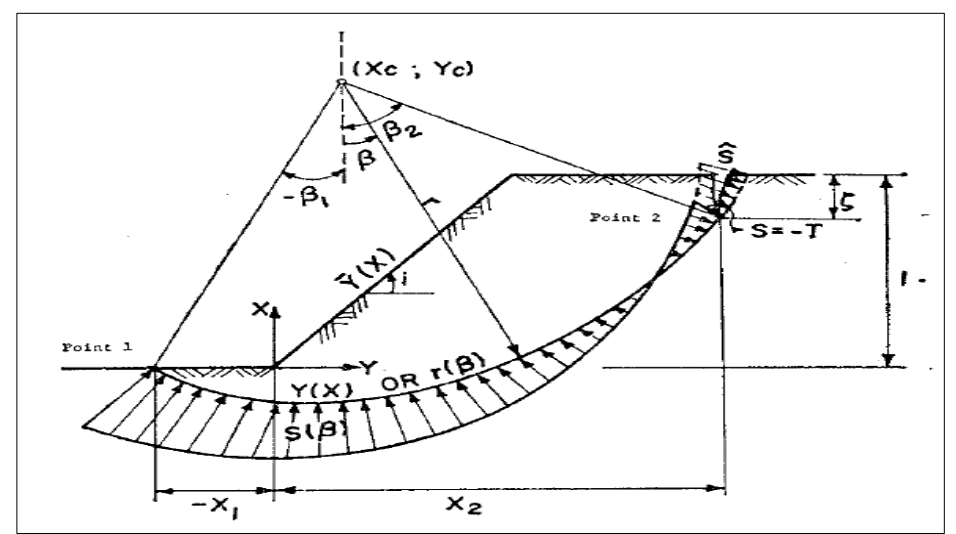

Gambar 2. Dasar ketentuan dan definisi dari tension crack (Sumber: Baker, 1981)

Reka Racana - 82 
halmana:

$z_{c} \quad=$ kedalaman tegangan retak $[\mathrm{m}]$,

$c \quad=$ kohesi $\left[\mathrm{kN} / \mathrm{m}^{2}\right]$,

$\phi \quad=$ sudut dari gesekan $\left[{ }^{\circ}\right]$,

$\gamma \quad=$ berat isi dari tanah $\left[\mathrm{kN} / \mathrm{m}^{2}\right]$.

\subsection{Teori Mohr-Coulumb}

Menurut Mohr (1900) dalam Das (2010) menyatakan bahwa keruntuhan material terjadi karena kombinasi kritis dari tegangan normal dan tegangan geser dan bukan hanya akibat tegangan normal atau tegangan geser dengan kondisi maksimum saja. Oleh karena itu, Persamaan 3 hubungan antara tegangan normal dan tegangan geser pada keruntuhan dapat dinyatakan dengan:

$$
\tau=f(\sigma)
$$

Keruntuhan Gambar 3 yang dinyatakan pada Persamaan 4 berbentuk garis lengkung. Untuk berbagai macam permasalahan mekanika tanah, garis lengkung itu tidak efisien untuk perkiraan tegangan geser dalam keruntuhan sebagai fungsi persamaan garis lurus dari tegangan normal (Coulomb, 1776). Fungsi persamaan garis dapat ditulis dengan:

$$
\tau=c+\sigma \tan \varnothing
$$

halmana:

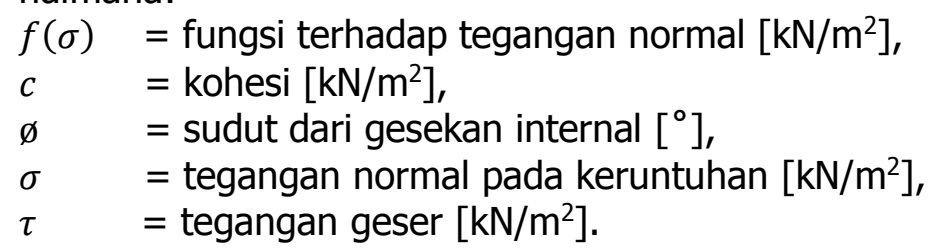

Persamaan diatas disebut kriteria kegagalan Mohr-Coulomb.

Pada tanah jenuh, total tegangan normal pada suatu titik Persamaan $\mathbf{5}$ adalah jumlah dari tegangan efektif $(\sigma)$ dan tekanan air pori $(u)$, atau:

$$
\sigma=\sigma^{\prime}+u
$$

Kriteria keruntuhan Mohr-Coulomb diekspresikan dalam tegangan geser dapat dinyatakan pada Persamaan 6 dengan:

$$
\tau=c^{\prime}+\sigma^{\prime} \tan \varnothing
$$

halmana:

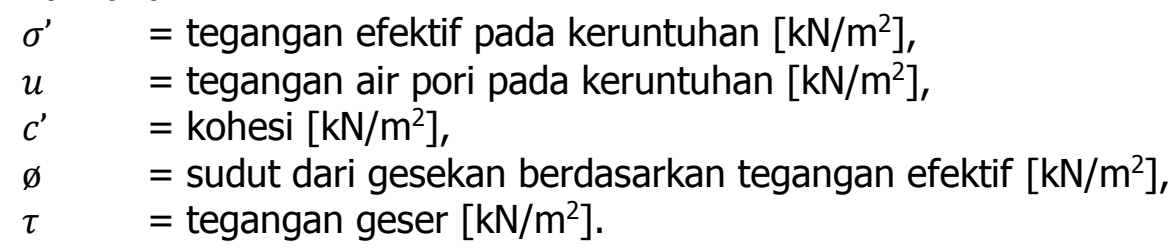




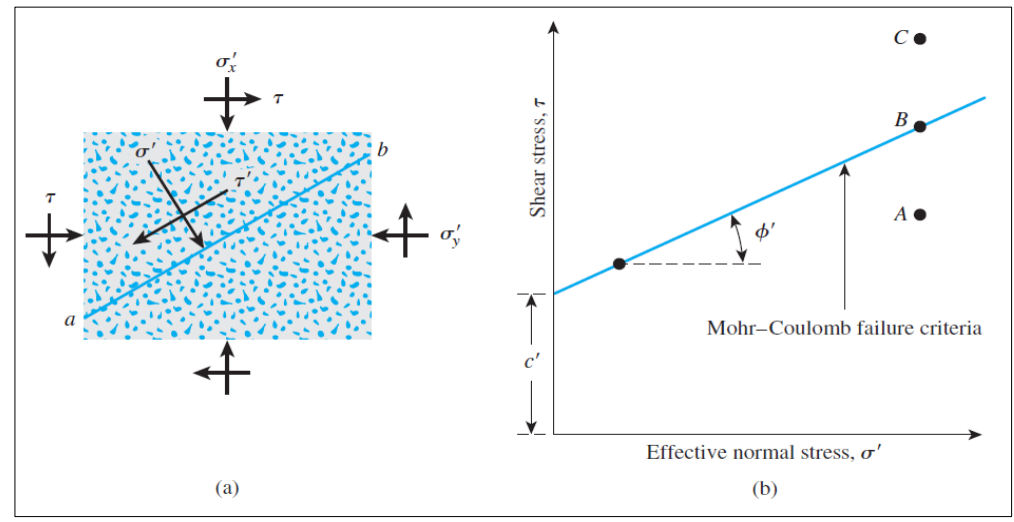

Gambar 3. Kriteria keruntuhan Mohr-Coulomb

(Sumber: Das, 2010)

\subsection{Finite Element Method (FEM)}

Faktor keamanan pada metode ini dapat diperoleh dari asumsi kriteria keruntuhan MohrCoulomb, yaitu dengan cara mengurangi parameter kekuatan secara bertahap berupa nilai-

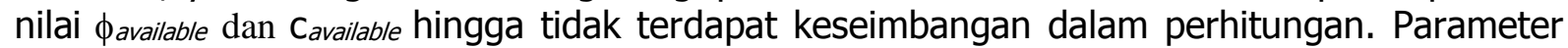
kekuatan yang sesuai dapat dinyatakan sebagai $\phi$ failure dan cfailure dan faktor keamanan $\eta_{\mathrm{fe}}$ (Persamaan 7) didefinisikan:

$$
\eta_{f e}=\frac{c_{\text {available }}}{c_{\text {failure }}}=\frac{\tan \emptyset_{\text {available }}}{\tan \emptyset_{\text {failure }}}
$$

halmana:

$\eta_{f e} \quad=$ angka keamanan terhadap kekuatan tanah,

$c_{\text {available }} \quad=$ kohesi yang tersedia $\left[\mathrm{kN} / \mathrm{m}^{2}\right]$,

$c_{\text {failure }} \quad=$ kohesi terjadi keruntuhan $\left[\mathrm{kN} / \mathrm{m}^{2}\right]$,

$\tan \emptyset_{\text {available }}=$ nilai tan dari sudut gesekan yang tersedia $\left[{ }^{\circ}\right]$,

$\tan \emptyset_{\text {failure }}=$ nilai tan dari sudut gesekan terjadi keruntuhan $\left[{ }^{\circ}\right]$.

\section{METODE PENELITIAN}

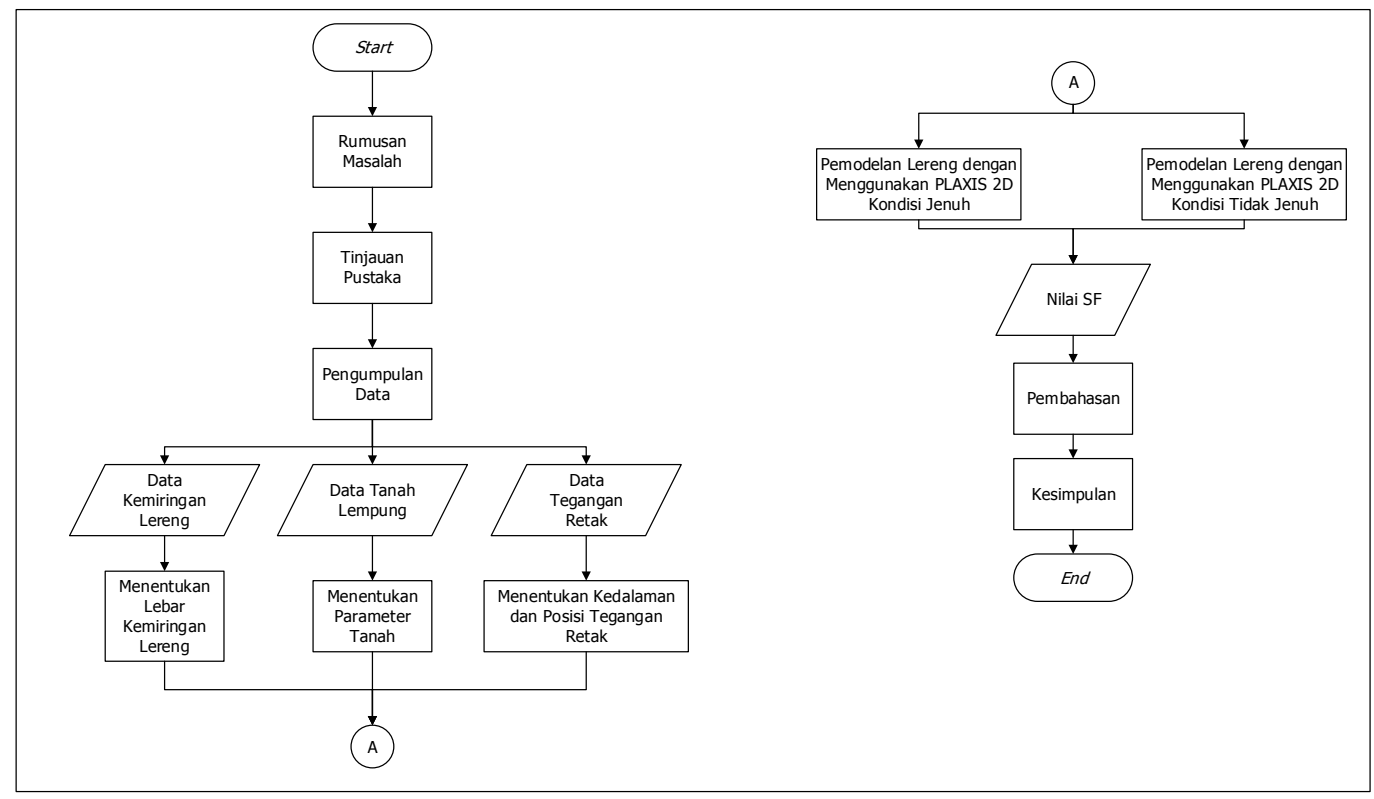

Gambar 4. Flowchart pemodelan analisis lereng menggunakan PLAXIS 2D

Reka Racana - 84 


\section{HASIL PENELITIAN DAN PEMBAHASAN}

\subsection{Parameter Tanah}

Berikut nilai parameter tanah lempung secara asumsi yang digunakan pada pemodelan:

1. $\gamma_{\text {sat }}=20,0\left[\mathrm{kN} / \mathrm{m}^{3}\right]$.

2. Yunsat $=18,0\left[\mathrm{kN} / \mathrm{m}^{3}\right]$.

3. $c=45,0\left[\mathrm{kN} / \mathrm{m}^{2}\right]$.

4. $\phi=5\left[{ }^{\circ}\right]$.

\subsection{Pemodelan Lereng}

Pemodelan lereng ini dilakukan dengan berbagai macam kemiringan lereng diantaranya $1 \mathrm{~V}$ : $1 \mathrm{H}, 1 \mathrm{~V}: 1,5 \mathrm{H}$ dan $1 \mathrm{~V}: 2 \mathrm{H}$ dimana ketinggian 10 meter dan lebar 10 meter, 15 meter dan 20 meter. Hal ini dilakukan dengan variasi titik tegangan retak (tension crack) pada posisi $6 \mathrm{~m}$, $9 \mathrm{~m}$ dan $12 \mathrm{~m}$ dari kemiringan lereng dengan mengasumsikan jenis tanah pada lereng adalah lempung kepasiran sedangkan untuk kedalaman tegangan retak sendiri yaitu 4,3m sesuai dengan kedalaman retakan secara teori dan sisanya yaitu asumsi sebesar $3 \mathrm{~m}$ dan $1 \mathrm{~m}$.

\subsection{Analisis Bentuk Keruntuhan Lereng pada Kondisi Tidak Jenuh}

Saat meninjau kemiringan 1:1 yang ditunjukkan pada Gambar 5 pengaruh tegangan retak pada bentuk keruntuhan hampir terjadi disemua posisi tegangan retak serta kedalaman kecuali pada saat posisi $6 \mathrm{~m}$ dengan kedalaman $1 \mathrm{~m}$ tidak memberikan pengaruh karena gayagaya (berat tanah) yang bekerja pada bidang keruntuhan lebih dominan dibandingkan berkurangnya kuat geser akibat adanya tegangan retak. Kemudian untuk kemiringan 1:1,5

Gambar 6 dan kemiringan 1:2 Gambar 7 tidak terjadi pengaruh tegangan retak (tension crack) bentuk keruntuhan pada saat kedalaman tegangan retak $1 \mathrm{~m}$ posisi $6 \mathrm{~m}$ dan $12 \mathrm{~m}$ serta kedalaman $3 \mathrm{~m}$ dan $4,3 \mathrm{~m}$ posisi $6 \mathrm{~m}$ sebab gaya yang melongsorkan dari tanah dipengaruhi oleh kemiringan lereng, posisi tegangan retak dan kedalaman tegangan retak. Hal itu dapat dilihat saat titik tinjauan terhadap seluruh kemiringan, dimana bentuk keruntuhan paling berpengaruh pada lereng yang semakin curam lalu saat posisi retakan semakin jauh dari puncak lereng dan saat kedalaman retakan semakin dalam. Berlaku pula untuk nilai faktor keamanan dimana dapat dilihat pada Tabel 1 bahwa semakin jauh posisi tegangan retak, semakin dalam tegangan retak serta semakin curam tegangan retak maka nilai faktor keamanan dari lereng tersebut semakin kecil.
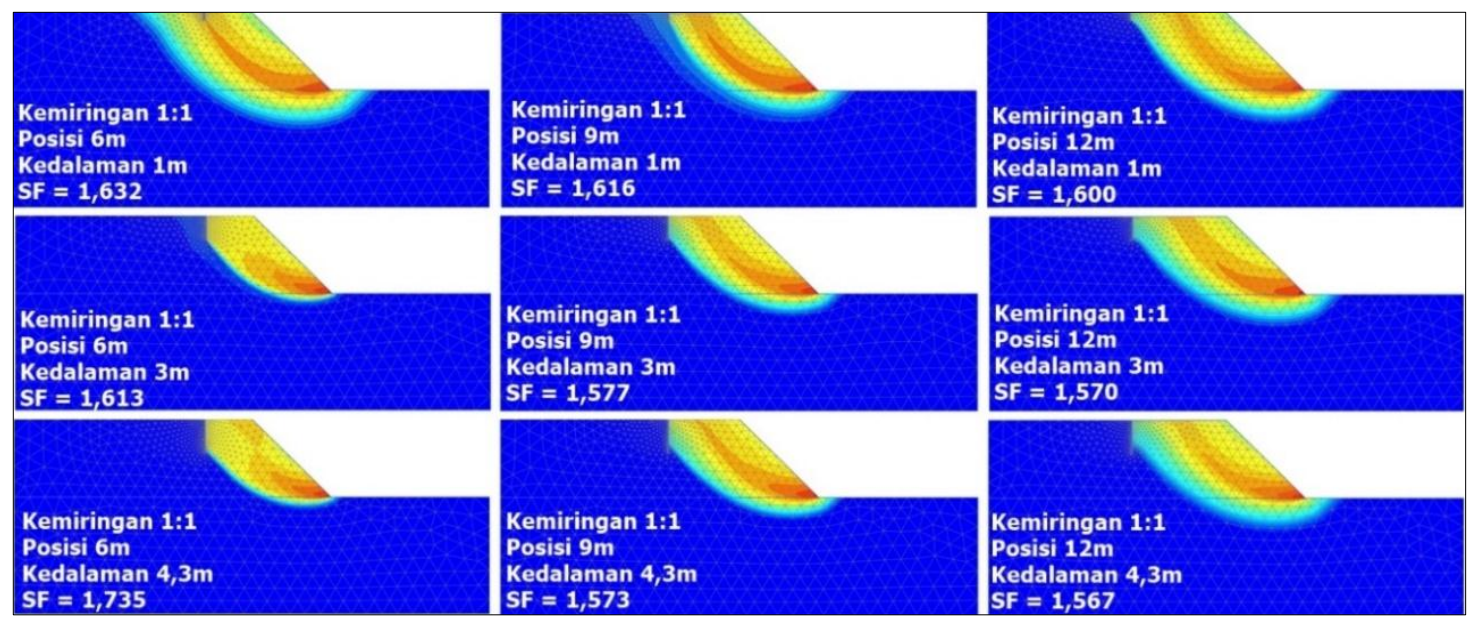

Gambar 5. Pemodelan kemiringan 1:1 saat kondisi tidak jenuh 


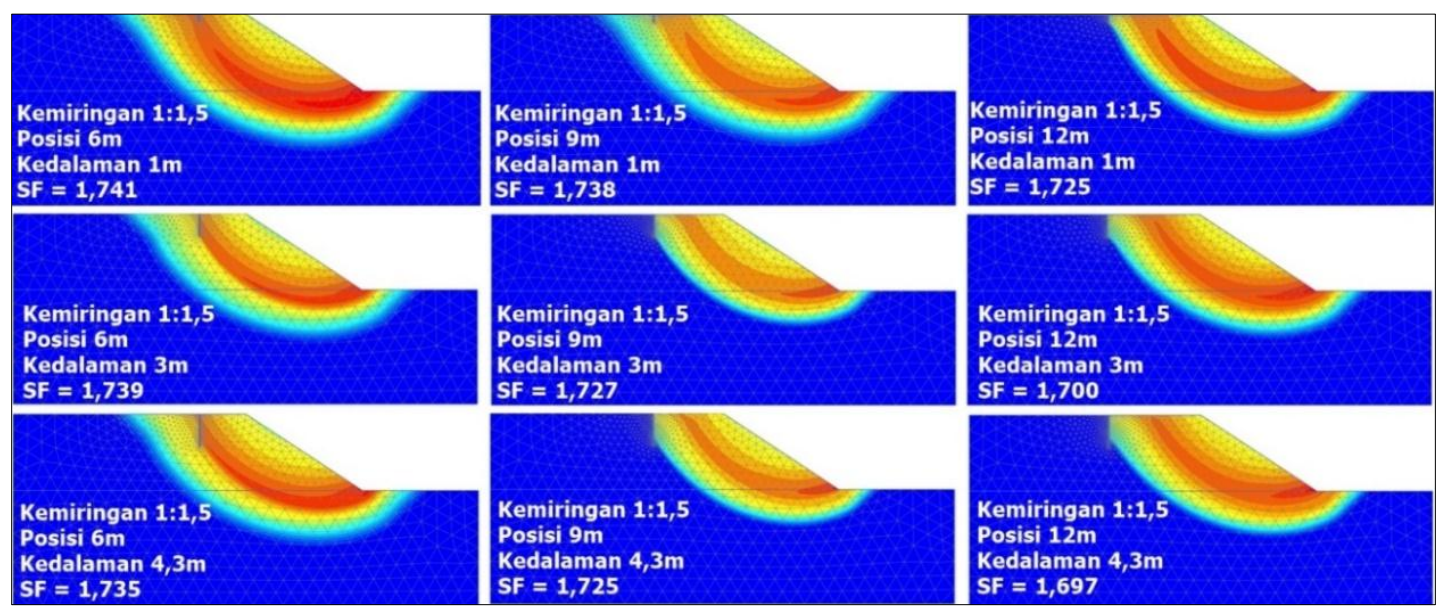

Gambar 6. Pemodelan kemiringan 1:1,5 saat kondisi tidak jenuh
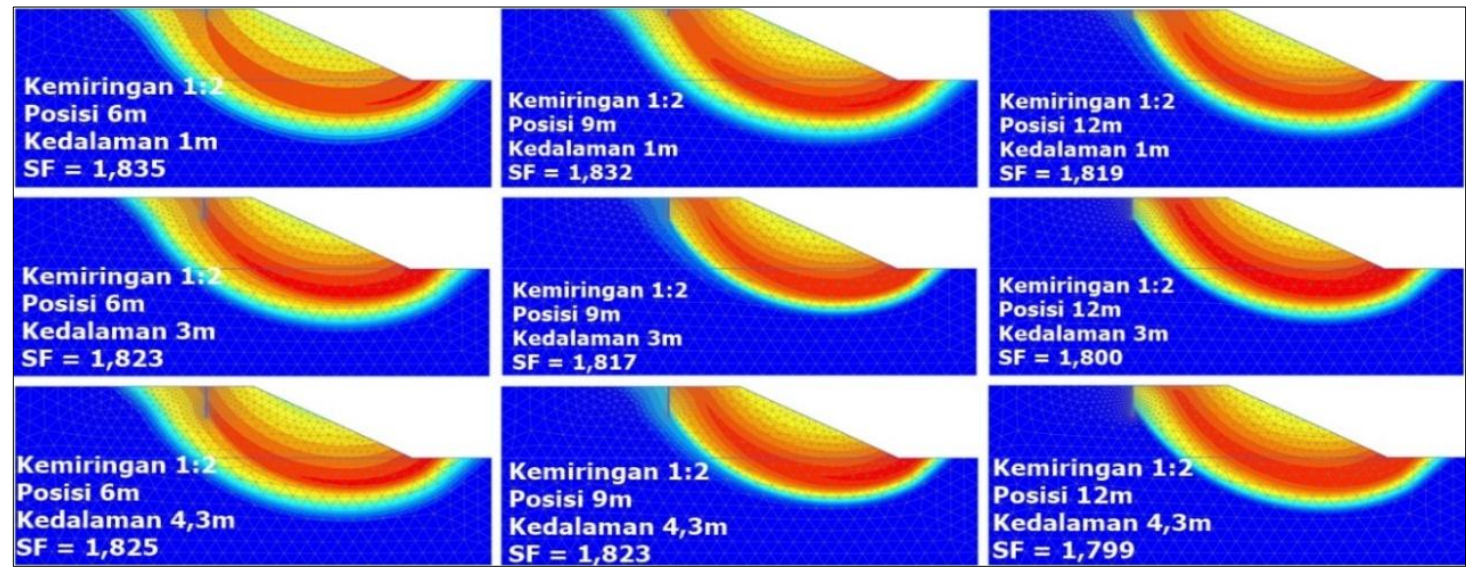

Gambar 7. Pemodelan kemiringan 1:2 saat kondisi tidak jenuh

Tabel 1. Nilai Faktor Keamanan Kondisi Tidak Jenuh

\begin{tabular}{|c|c|c|c|}
\hline \multicolumn{4}{|c|}{ Pemodelan dengan Satu Kedalaman Tegangan retak Kondisi Tidak Jenuk } \\
\hline Pemodelan & \multicolumn{3}{|c|}{ Faktor Keamanan } \\
\hline \multicolumn{4}{|l|}{ Kemiringan 1:1 } \\
\hline & Posisi $6 \mathrm{~m}$ & Posisi $9 \mathrm{~m}$ & Posisi $12 \mathrm{~m}$ \\
\hline kedalaman $1 \mathrm{~m}$ & 1,632 & 1,616 & 1,600 \\
\hline kedalaman 3m & 1,613 & 1,577 & 1,570 \\
\hline kedalaman $4,3 \mathrm{~m}$ & 1,612 & 1,573 & 1,567 \\
\hline \multicolumn{4}{|l|}{ Kemiringan $1: 1,5$} \\
\hline & Posisi $6 \mathrm{~m}$ & Posisi $9 \mathrm{~m}$ & Posisi $12 \mathrm{~m}$ \\
\hline kedalaman $1 \mathrm{~m}$ & 1,741 & 1,738 & 1,725 \\
\hline kedalaman $3 \mathrm{~m}$ & 1,739 & 1,727 & 1,700 \\
\hline kedalaman 4,3m & 1,735 & 1,725 & 1,697 \\
\hline \multicolumn{4}{|l|}{ Kemiringan $1: 2$} \\
\hline & Posisi $6 \mathrm{~m}$ & Posisi $9 \mathrm{~m}$ & Posisi $12 \mathrm{~m}$ \\
\hline kedalaman $1 \mathrm{~m}$ & 1,835 & 1,832 & 1,819 \\
\hline kedalaman $3 \mathrm{~m}$ & 1,823 & 1,817 & 1,800 \\
\hline kedalaman 4,3m & 1,825 & 1,823 & 1,799 \\
\hline
\end{tabular}




\subsection{Analisis Bentuk Keruntuhan Lereng pada Kondisi Jenuh}

Gambar 8 menunjukkan bahwa tanah mengalami collapse atau terjadi kelongsoran sebab saat meninjau nilai faktor keamanan pada kemiringan 1:1 dengan kondisi jenuh nilainya berada dibawah satu sebelum terjadinya retakan akibat tegangan air pori yang bekerja pada lereng tersebut lebih besar dibandingkan kekuatan geser dari tanah. Lalu untuk kemiringan 1:1,5 Gambar 9 dan kemiringan 1:2 Gambar 10 dengan kondisi jenuh, bentuk keruntuhan terjadi pada posisi $9 \mathrm{~m}$ dan $12 \mathrm{~m}$ dengan kedalaman $3 \mathrm{~m}$ dan $4,3 \mathrm{~m}$. Hal itu menunjukkan bahwa kuat geser yang bernilai nol pada tegangan retak memberikan pengaruh terhadap bentuk keruntuhannya serta tekanan hidrostatis yang bekerja pada lereng tersebut memberikan tegangan geser yang lebih besar. Sedangkan saat bentuk keruntuhan tidak terjadi pada tegangan retak maka keruntuhan tersebut disebabkan oleh tegangan air pori yang bekerja pada taha tersebut serta kemiringan lereng. Ketika meninjau nilai faktor keamanan Tabel 2 pada lereng tersebut menunjukkan sama seperti kondisi lainnya, bahwa kemiringan lereng semakin curam, posisi tegangan retak semakin jauh dari lereng dan kedalaman tegangan retak semakin dalam menunjukkan bahwa semakin kecil nilai faktor keamanannya.

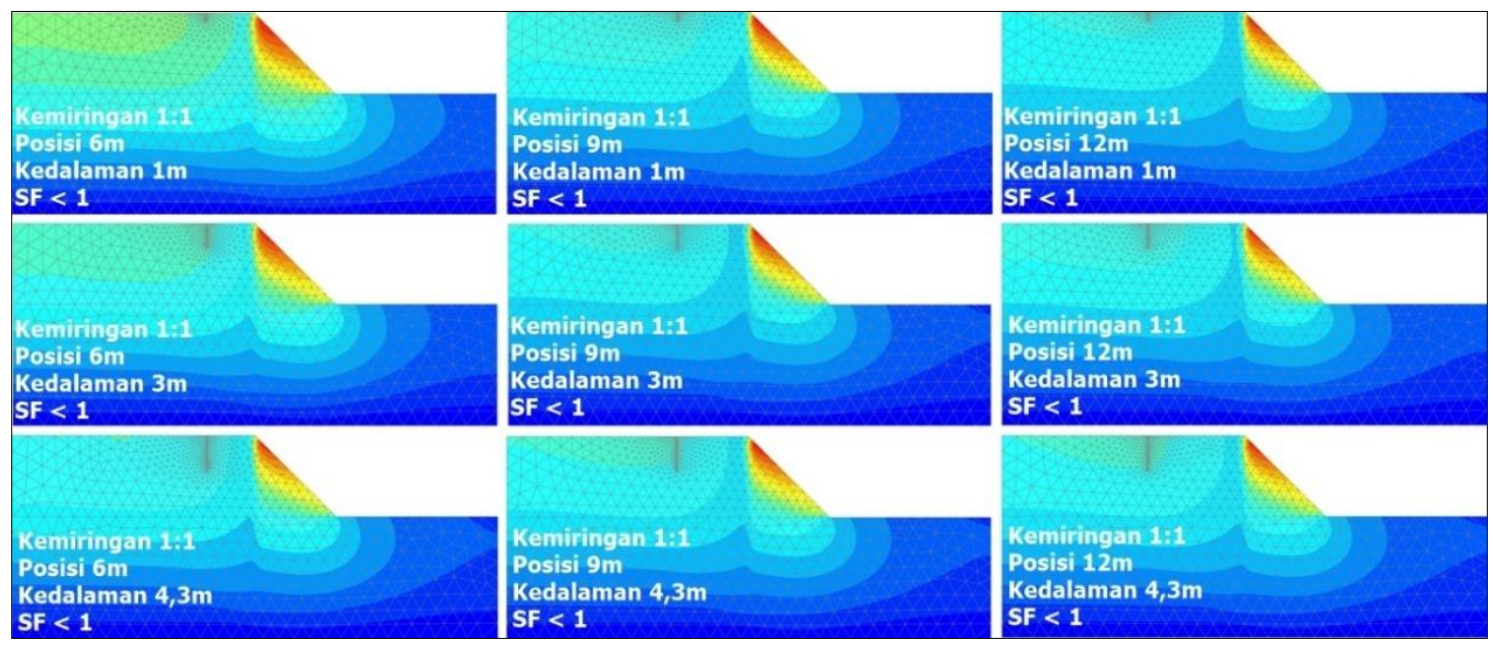

Gambar 8. Pemodelan kemiringan 1:1 saat kondisi jenuh
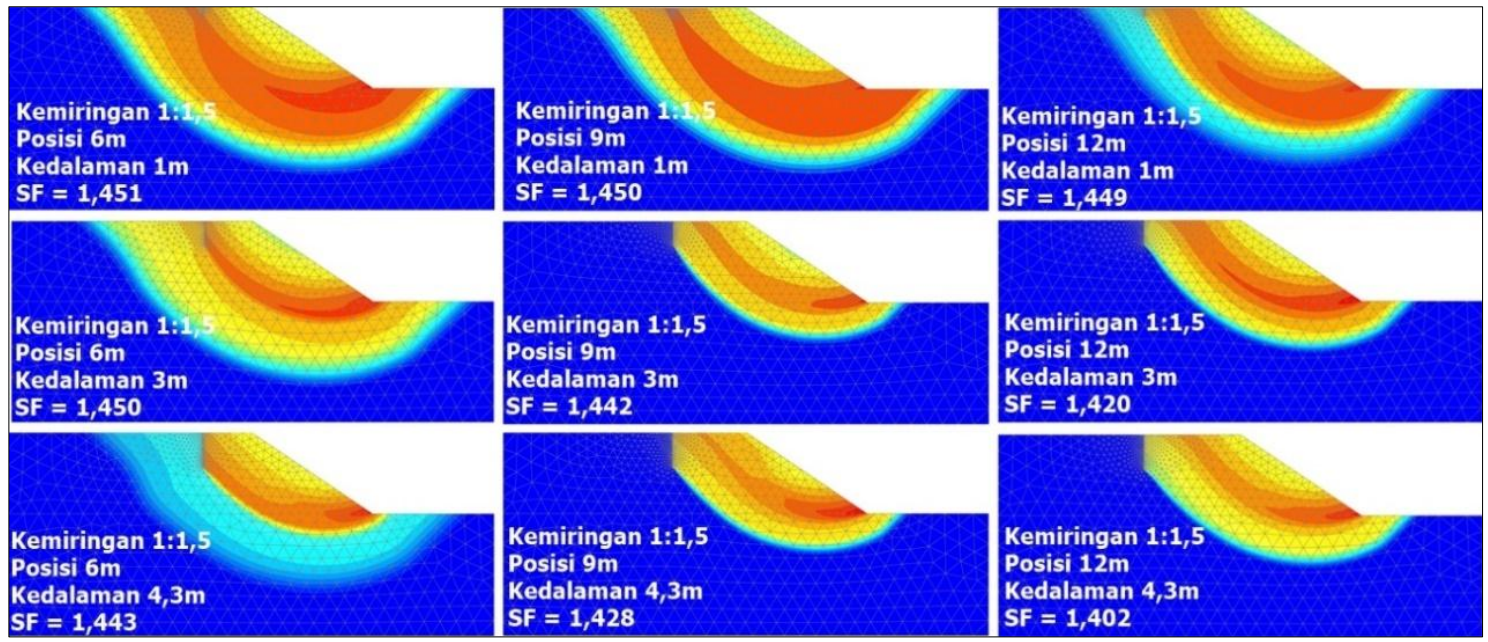

$\mathrm{SF}=1,449$

Gambar 9. Pemodelan kemiringan 1:1,5 saat kondisi jenuh 

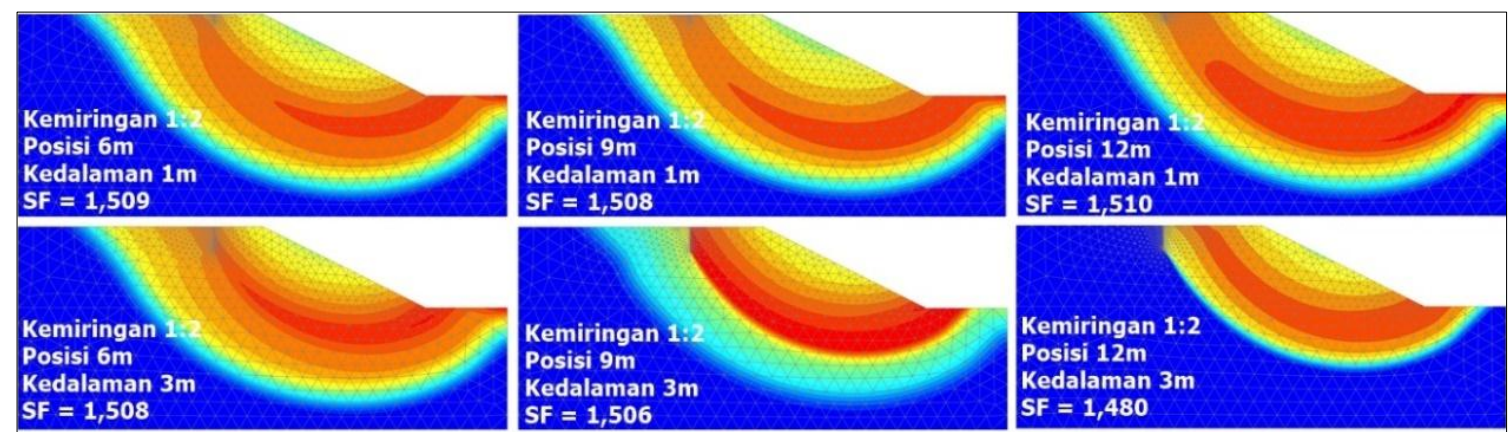

$=1.508$
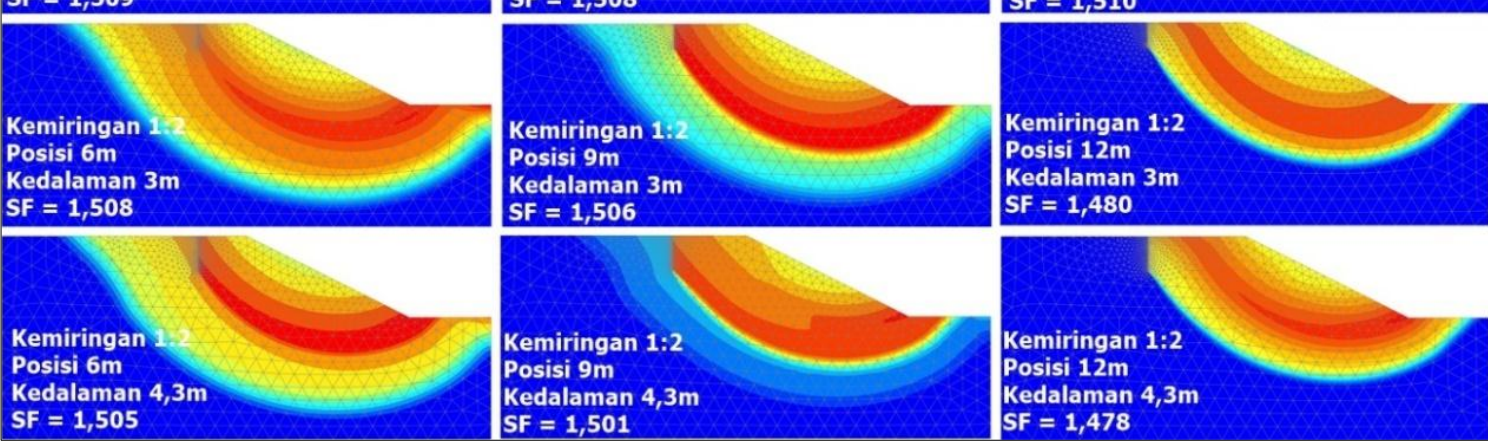

Kemiringan 1

Posisi $9 \mathrm{~m}$

Kedalaman $3 \mathrm{~m}$

$S F=1,506$

$\mathrm{SF}=1,480$

Gambar 10. Pemodelan kemiringan 1:2 saat kondisi jenuh

Tabel 1. Nilai Faktor Keamanan Kondisi Jenuh

\begin{tabular}{|c|c|c|c|}
\hline \multicolumn{4}{|c|}{ Pemodelan dengan Satu Kedalaman saat Kondisi Tidak Jenuh } \\
\hline Pemodelan & \multicolumn{3}{|c|}{ Faktor Keamanan } \\
\hline \multicolumn{4}{|l|}{ Kemiringan $1: 1$} \\
\hline & Posisi $6 \mathrm{~m}$ & Posisi $9 \mathrm{~m}$ & Posisi $12 \mathrm{~m}$ \\
\hline kedalaman $1 \mathrm{~m}$ & $<1$ & $<1$ & $<1$ \\
\hline kedalaman $3 \mathrm{~m}$ & $<1$ & $<1$ & $<1$ \\
\hline kedalaman 4,3m & $<1$ & $<1$ & $<1$ \\
\hline \multicolumn{4}{|l|}{ Kemiringan $1: 1,5$} \\
\hline & Posisi $6 \mathrm{~m}$ & Posisi $9 \mathrm{~m}$ & Posisi $12 \mathrm{~m}$ \\
\hline kedalaman $1 \mathrm{~m}$ & 1,451 & 1,45 & 1,449 \\
\hline kedalaman $3 \mathrm{~m}$ & 1,450 & 1,442 & 1,420 \\
\hline kedalaman $4,3 \mathrm{~m}$ & 1,443 & 1,428 & 1,402 \\
\hline \multicolumn{4}{|l|}{ Kemiringan $1: 2$} \\
\hline & Posisi $6 \mathrm{~m}$ & Posisi $9 \mathrm{~m}$ & Posisi $12 \mathrm{~m}$ \\
\hline kedalaman $1 \mathrm{~m}$ & 1,509 & 1,508 & 1,510 \\
\hline kedalaman $3 \mathrm{~m}$ & 1,508 & 1,506 & 1,480 \\
\hline kedalaman 4,3m & 1,505 & 1,501 & 1,478 \\
\hline
\end{tabular}

\section{KESIMPULAN DAN SARAN}

\subsection{Kesimpulan}

Saat setelah dilakukan analisis stabilitas lereng dengan pengaruh variasi kedalaman tegangan retak, variasi kemiringan tegangan retak serta variasi posisi tegangan retak untuk tiga kondisi pemodelan dapat ditarik kesimpulan bahwa:

a. Semakin jauh posisi tegangan retak, semakin dalam tegangan retak serta semakin curam kemiringan lereng maka semakin kecil pula nilai faktor keamanan dari lereng tersebut.

b. Kondisi jenuh dan tidak jenuh pada pemodelan tersebut memberikan pengaruh terhadap nilai faktor keamanan.

c. Saat kondisi jenuh, nilai faktor keamanan lebih kecil dibandingkan dengan kondisi tidak jenuh. 
d. Bentuk keruntuhan tepat terjadi pada tegangan retak secara berkesinambungan dipengaruhi oleh kedalaman tegangan retak, posisi tegangan retak serta kemiringan lereng.

\subsection{Saran}

Studi selanjutnya disarankan pemodelan atau analisis ini dilakukan menggunakan metode lain dan jika akan digunakan metode yang sama, disarankan untuk mencoba pemodelan menggunakan PLAXIS 3D sehingga dapat dilakukan perbandingan.

\section{DAFTAR RUJUKAN}

Baker, R. (1981). Tensile Strength, Tension Cracks, and Stability of Slopes. SOILS AND FOUNDATION, 21(2), 1-2.

Das, B. M. (2010). Principles of Geotechnical Engineering. USA: Cengage Learning.

U.S. Geological Survey. (2004, Juli). Landslide Types and Processes. Dipetik Maret 4, 2017, dari USGS science for a changing world: https://pubs.usgs.gov/fs/2004/3072/ 